\title{
EFFECT OF COUNSELING WITH MULTIMEDIA VIDEO ON CLEAN AND HEALTHY BEHAVIOR AMONG ELEMENTARY SCHOOL STUDENTS IN BANTUL, YOGYAKARTA
}

\author{
Suratini, Catur Sari Nurmaninatri \\ School of Nursing, Aisyiyah University at Yogyakarta
}

\begin{abstract}
BACKGROUND: Healthy behavior should be practiced as early as possible in life. Children like playing. Therefore to be effective healthy behavior messages should be delivered while they are playing. Multimedia video had the potential to convey clean and healthy behavior messages. This study aimed to determine the effect of counseling with multimedia video on clean and healthy behavior among elementary school students.

SUBJECT AND METHODS: This was a quasi-experiment with before and after intervention design. A sample of 20 elementary students was selected from Elementary School 2 Jambidan, Banguntapan, Bantul, Yogyakarta. The intervention included counseling with multimedia video. The intervention contained clean and healthy behavior messages. The dependent variable was clean and healthy behavior measured by a structured questionnaire. Difference in the proportion of students with clean and healthy behavior before and after intervention was compared and tested by chi square.

RESULTS: 15 students (75\%) had clean and healthy behavior before intervention. 16 students (80\%) had clean and healthy behavior after intervention. This increase in the propotion of clean and healthy behavior before and after the intervention was statistically significant $(\mathrm{p}<0.001)$.

CONCLUSION: Counseling with multimedia video can be used to increase clean and healthy behavior among elementary students.
\end{abstract}

Keywords: counseling, multimedia, clean and healthy behavior 